\title{
Violations of the law in hospital medical waste management
}

* Chair and Department of Public Health, Medical University of Lublin;

e-mail: marzenafurtakniczyporuk@umlub.pl

\section{Keywords:}

waste, hazardous clinical waste, hospital, waste management

\begin{abstract}
The production of clinical waste is an inevitable consequence of rendering health services, including hazardous infectious clinical waste containing live pathogenic microorganisms, which can be the potential source of infections and infectious diseases. For this reason, the management of waste collected during rendering health services most of all requires responsibility for the security of both patients and staff on the part of the managers of healthcare-institutions. The results of hospital inspections in the field of clinical-waste management conducted by the Voivodeship Sanitary Inspection in Lublin, which were made available for the purpose of this paper, have shown numerous irregularities concerning the management of hazardous clinical waste. Most of the irregularities involved the condition of premises and the temporary storage of clinical waste.
\end{abstract}

(c) IOŚ-PIB

\section{INTRODUCTION}

Clinical waste includes solid, liquid or gaseous substances produced in connection with rendering health services, as a result of diagnostic procedures, treatment, care and health prevention, as well as scientific research and experiments in the field of medicine [Ustawa...2012]. Thirteen types of clinical waste are listed in the waste catalogue in sub-group 1801, which have further been divided into hazardous and other than hazardous waste (general waste) [Rozporządzenie...2014]. As far as hazardous clinical waste is concerned, these are, for example, body parts and organs, blood containers, chemicals, cytotoxic and cytostatic medicines, dental amalgam waste and food and patient-care residue from infectious-disease wards. The infectious properties of the waste mean that the substances and preparations contain live micro-organisms, or their toxins, which are considered by the studies as the cause of diseases in people and other living organisms. The danger factor in the context of the waste results directly from the content of pathogens, which is related to the content of organic tissue, biological-infection factors such as bacteria, viruses and fungi, and hazardous chemical substances from medications past their expiry date or cytostatic and cytotoxic medicines. Therefore, hazardous clinical waste constitutes a potential cause of the spread of infections and epidemics being a threat to the health and lives of people and a threat to the natural environment, if they are managed in an improper way. For this reason, the management of hazardous clinical waste in hospitals, where the largest volume of such waste is produced, gains particular significance on account of security.

Thus, medical waste management (especially in terms of dangerous waste) by hospitals, which produce tonnes of such waste, is of particular importance due to the need for the guarantee of safety. According to the current legal definition, waste management is understood as collection, transport, and waste processing, together with supervising these actions and the subsequent management of waste recovery and disposal sites, and actions taken by waste dealers or brokers [Ustawa...2012]. One of the most important elements in waste management is its collection [Korzeniowski 2014], which is understood as gathering waste before being transported to processing sites, and preliminary step includes sorting, which does not lead to any essential change of its character, makeup or classification, as well as temporary waste storage [Ustawa...2012]. The subject of this paper is waste collection, which is among the most problematic issues in hospitals, from separate collection of waste to internal transport and temporary storage. The problems in the above-mentioned sphere are confirmed by the analysis of the reports of control activities conducted by the Regional Sanitary Inspection in Lublin, which undoubtedly show violations of the law in hospital waste management.

As for the remaining elements of waste management, that is, transport, waste processing, management of waste 
Table 1. The number of hospital inspections concerning clinical-waste management, together with their locations, in individual years.

\begin{tabular}{|c|c|c|}
\hline Year & $\begin{array}{l}\text { Number of } \\
\text { inspections }\end{array}$ & Hospitals city \\
\hline 2010 & 8 & $\begin{array}{l}\text { Bychawa, Radzyń Podlaski, Włodawa, Tomaszów Lubelski, Międzyrzec Podlaski, Poniatowa, } \\
\text { Janów Lubelski, Opole Lubelskie }\end{array}$ \\
\hline 2011 & 9 & $\begin{array}{l}\text { Krasnystaw, Hrubieszów, Poniatowa, Szczebrzeszyn, Świdnik, Puławy, Janów Lubelski, Radzyń } \\
\text { Podlaski, Bełżyce }\end{array}$ \\
\hline 2012 & 5 & Bychawa, Radzyń Podlaski, Tomaszów Lubelski, Kraśnik, Puławy \\
\hline 2013 & 2 & Szczebrzeszyn, Łęczna \\
\hline 2014 & 10 & $\begin{array}{l}\text { Parczew, Świdnik, Tomaszów Lubelski, Radzyń Podlaski, Lubartów, Krasnystaw, Bychawa, } \\
\text { Bełżyce, Kraśnik (x2) }\end{array}$ \\
\hline 2015 & 13 & $\begin{array}{l}\text { Międzyrzec Podlaski, Łuków (x2), Tomaszów Lubelski, Szczebrzeszyn (x2), Puławy, Kraśnik, } \\
\text { Krasnystaw, Łęczna, Hrubieszów, Opole Lubelskie, Janów Lubelski }\end{array}$ \\
\hline 2016 & 9 & Bychawa, Łuków, Międzyrzec Podlaski, Janów Lubelski, Parczew, Opole Lubelskie \\
\hline
\end{tabular}

recovery and disposal sites, and the actions taken in the course of waste trading, they require a separate overview due to their broad and specialist scope. However, it seems important to stress that these services are usually provided by external, specialist contractors. It is their responsibility to ensure safe transportation of hazardous medical waste [Ustawa...2011; Furtak-Niczyporuk 2015], and subsequent preparation and documentation of its disposal through incineration [Rozprządzenie...2016; Rozporządzenie...2014] or recovery in the case of some medical waste that does not pose any risks [Rozprządzenie...2015]. It is worth noting that there are very few hospitals in Poland that are equipped with special installations for the disposal of hazardous medical waste. However, the lack of any such installations in the entire territory of Lubelskie Voivodeship was the main reason to conduct a research on this subject.

\section{MATERIAL AND METHODS}

The research was carried out by way of examining the documents provided by the State Voivodeship Sanitary Inspector in Lublin (the Voivodeship Sanitary Inspection in Lublin). In addition, the method applied was the examination of literature on the subject and the legal regulations concerning clinical-waste management. The scope of the research included hospital-inspection results in the Lubelskie Voivodeship in the field of clinical waste between 2010 and 2016 conducted by the Voivodeship Public Health Inspection (WIS) in Lublin. The research material included the results for 56 inspections concerning clinical-waste management carried out in 27 hospitals.

\section{RESULTS AND DISCUSSION}

The definition of waste indicates that it is a substance or object that has been disposed of, is planned to be disposed of, or should be disposed of, by its owner [Ustawa 2012]. The key element of the definition of waste is the term disposal, because an object becomes waste at the moment of 'disposing of' it [Górski 2005]. However, disposal should not be understood as losing control over the object, but as a material change in its use (different from the intended one), which can cause serious negative consequences for humans and the environment [Górski 2009]. Clinical-waste management is a process consisting of the following consecutive stages: collection, storage, labelling, transport to an internal disposal site, temporary storage and transport to a waste treatment plant [Górski 2009]. In each of the waste management stages, the hospitals are required to comply with the obligations provided by the law. The research shows that over the last seven years, the Voivodeship Public Health Inspection has carried out 56 inspections in 27 hospitals in the Lubelskie Voivodeship area. The inspections were carried out within the ongoing supervision schedule or as an intervention. Table 1 presents the number of inspections conducted in hospitals in individual cities.

The Inspector has issued a total of nine administrative decisions ordering the hospitals to remove defects related to irregularities in clinical-waste management. Since 2014, the number of these decisions has been growing each year. In 2016, despite the fact that the number of inspections was lower than in the previous year, the number of administrative decisions concerning irregularities in clinical-waste management in healthcare institutions increased. A detailed analysis of the number of inspections is presented in Chart 1. 


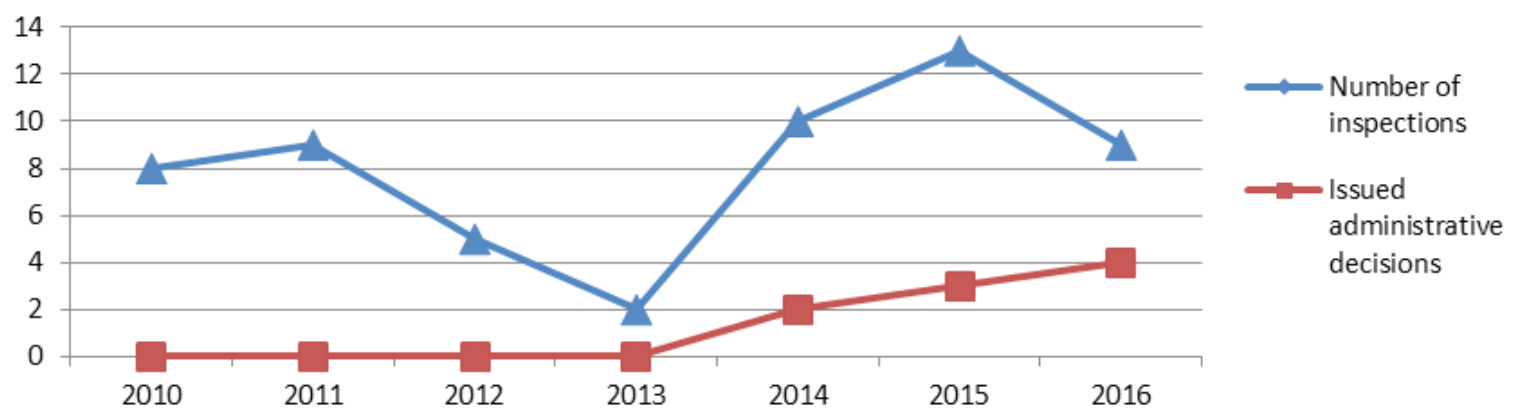

Chart 1. The number of hospital inspections concerning clinical-waste management, together with the issued administrative decisions, in individual years.

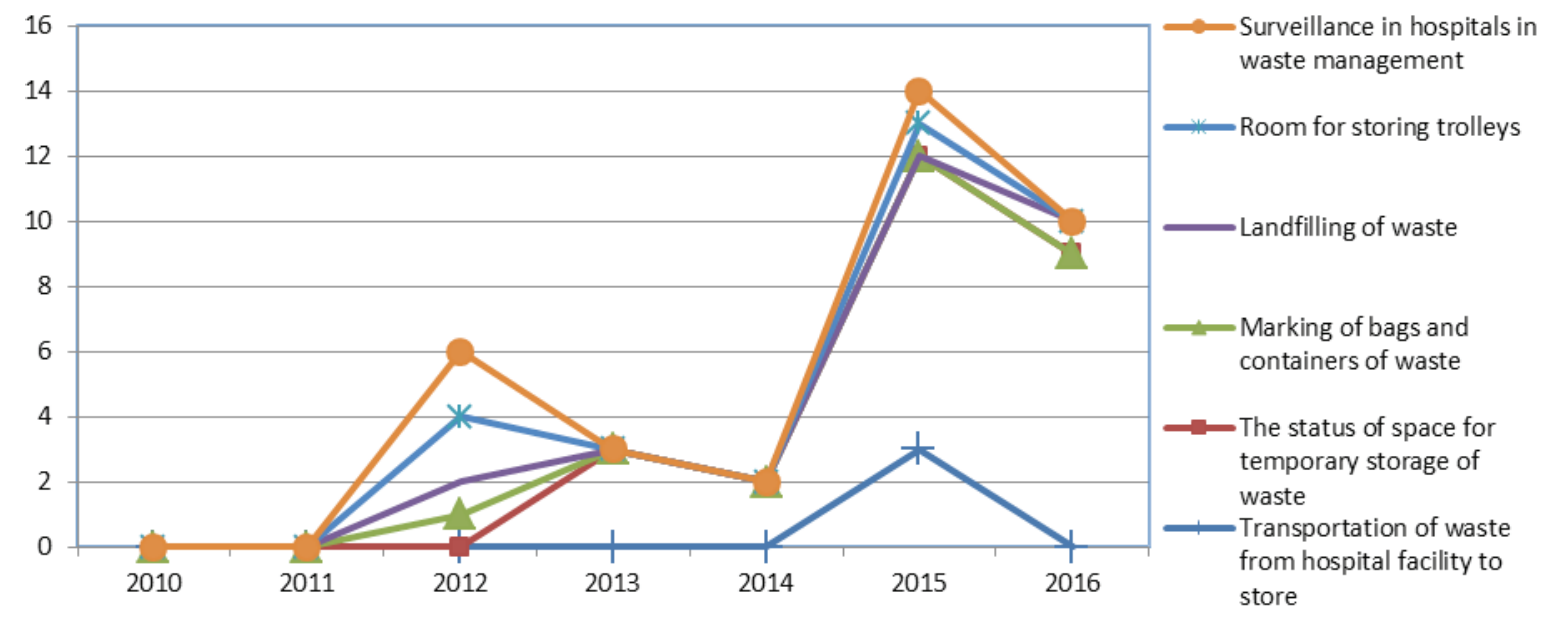

Chart 2. Irregularities in clinical-waste management in hospitals in individual years.

It is possible to categorise the detected irregularities in clinical-waste management. The first and the most extensive category of irregularities in clinical-waste management concerns the condition of premises and the conditions of the temporary storage of clinical waste. The next categories concerned the labelling of bags and containers and the supervision of clinical-waste management in hospitals. A visual representation of individual categories of irregularities in clinical-waste management is shown in Chart 2.

The largest number of irregularities involved the condition of premises where the clinical waste was stored. Hazardous clinical waste marked with the code $180102^{*}$, such as body parts and organs, blood containers and preservatives used in its storage, and waste marked with the code 180103*, which contained live pathogenic micro-organisms or their toxins, were stored next to general waste, and their storage temperature was $22^{\circ} \mathrm{C}$. The temporary storage of waste until it is handed over for transportation (FurtakNiczyporuk 2015] and treatment [Furtak-Niczyporuk 2012] is the responsibility of entities producing clinical waste. The storage of waste has to be performed in disposal sites adapted for the purpose, which requires proper conditions for the storage of waste in compliance with sorting principles (Furtak-Niczyporuk 2013). It means that the waste must be placed in designated compartments and places, where the required temperature for individual types of waste is provided. This is based on the need to prevent the spreading of pathogenic micro-organisms onto other types of waste. The storage of clinical waste with general waste constituted the threat of transmitting micro-organisms from hazardous waste onto general waste. The condition could result in negative consequences for the health and lives of people, as hazardous clinical waste needs to be neutralised by way of thermal-waste treatment by incineration, while general waste is subject to different processes, such as preparing for re-use, recycling or recovery. Moreover, the multiplication and spreading of pathogenic micro-organisms is possible due to the high storage temperature, exceeding the permissible level by a factor of over two.

Subsequent irregularities in the area of premises allotted for clinical-waste storage included the poor technical and sanitary condition of disposal sites, including defects in tiles on floors; dusty, dirty, and damp walls, and ceilings with coarse surfaces and chipped paint; holes over disposal-site entrance doors not being secured with nets, and damaged entrance doors to waste-disposal sites. The temporary 
storage of clinical waste, including the hazardous kind, requires special security measures. The obligation of the owner, holder or manager of real property is to maintain it in a good hygienic and sanitary condition in order to prevent infections and infectious diseases [Ustawa...2008]. For this reason, premises where such waste is temporarily stored should have walls made of smooth materials, which are easy to clean and sterilise. Such premises should also be secured from unauthorised access. In addition, ventilation grilles and other holes should also be secured from insects, rodents and other animals. We also need to bear in mind that the general requirements lay down the conditions for buildings, which should be used in accordance with their intended use and in compliance with environmental requirements, and which should be maintained in an appropriate technical and aesthetic condition, not allowing the excessive deterioration of the building's utility properties and technical efficiency [Ustawa... 1994]. Furthermore, irregularities on the sites of the temporary storage of clinical waste included the lack of hygiene facilities, and improperly equipped hygiene facilities, including the lack of washbasins with running hot and cold water to enable staff responsible for storing waste keep their hands clean. The hygiene facility should have a washbasin with hot and cold water, soap and hand disinfectant dispensers, and disposable towels. The facility should be located inside the disposal site or directly next to it.

The second category of irregularities in healthcare institutions was related to the improper transportation of clinical waste to the premises of temporary storage, including the poor condition of the means of transport; openwork structures in the carts used for transporting waste; the low capacity of carts used for transporting waste; improper methods of transporting waste; using the same cart for transporting clinical waste and dirty laundry; the lack of a lid closing the cart; no place to wash and sterilise carts used for transporting waste; and no place to temporarily store the carts. The internal transporting of clinical waste to the premises of their temporary storage should be carried out in such a way that direct contact of other people with the transported materials is impossible. It means that the carts used for transporting clinical waste should be made of materials with smooth surfaces and have built-up sides resistant to cuts and tightly closed lids. In addition, the carts must have enough capacity to store a couple of large waste bags. Waste carts must not serve the purpose of transporting other things, on account of the possibility of transmitting pathogenic micro-organisms, which might lead to the spread of diseases. In order to reduce the number of biological pathogens, after each use, the carts should be washed and sterilised with the use of physical and chemical methods in special sites reserved for this purpose. . Only then the carts should be stored in designated premises until next use.

The next category of irregularities in clinical-waste management in healthcare institutions was related to insufficient labelling to identify the type of waste stored in bags and containers (no codes). The visible labelling of containers or bags is essential, as it facilitates their identification. The labelling should include the type of waste, along with its code and the place where they were produced, indicating the producer of waste and its registered office, and an additional indication of the original location of the waste production, for example, the name of a ward. The labelling should also include the date of closing the bag, or the date of opening in case of a container. The hospitals usually use adhesive labels with a place to enter the required information. The person closing the bag is responsible for the labelling, confirming the completed activity with his/her signature. The labelling of waste bags or containers is of particular importance in the case of clinical waste, part of which can constitute hazardous waste. These in turn can pose a genuine threat to the health and lives of people having contact with them. Therefore, leaving waste bags or containers without labels to identify the type of waste constitutes a particular threat to employees loading and unloading waste bags during transportation to the site of temporary storage, placing the bags in a disposal site and passing over the waste for further transportation to waste-treatment plants. Precautionary measures are vital at each of these stages of clinical-waste management.

The last category of irregularities in clinical-waste management in healthcare institutions involved the failure to provide internal control in the field of clinical-waste management. The creation of an internal control system by the hospital departments for sanitary and epidemiological affairs is a prerequisite to the proper operation of a medical facility, which is obliged to implement measures aimed at preventing the spread of infections and infectious diseases. The internal control of clinical-waste management starts with developing procedures for clinical-waste management and is followed by updating them on an ongoing basis. The control system, through the training of people having contact with the produced waste, including medical staff, employees responsible for maintaining cleanliness and order, employees dealing with the transportation of waste and through further control of the storage of waste, constitutes a crucial element in the process of preventing epidemics in healthcare institutions.

\section{CONCLUSION}

Compliance with strict hygiene principles is the basis of clinical-waste management in healthcare institutions that should be carried out through ensuring compliance with sanitary and epidemiological procedures and the training of personnel, both medical and technical, which to a large extent prevents infections [Duane et al. 2009]. As the presented research results indicate, there are still numerous irregularities in the field of clinical-waste management. Inappropriate technical and sanitary conditions on the site, where waste is temporarily stored, or the inappropriate transportation of waste, are serious omissions in the 
hospitals' internal control. These irregularities are not incidents detected only during inspections but result from incorrect practices adopted by hospitals. Moreover, the failure to provide labelling identifying the type of waste stored in bags and containers proves that the staff have not been sufficiently trained in the field of waste management [Michalak 2012]. The security of patients in healthcare institutions, to whom medical services are being rendered, is closely connected with proper clinicalwaste management, which unconditionally requires the ongoing implementation of measures aimed at controlling the hospital's epidemiological situation, which some of the hospitals have not done. A healthcare institution is required to initiate preventive measures in the field of spread of infections and infectious diseases, which involves ongoing risk assessment concerning infections, and its monitoring and internal control of compliance with the procedures of clinical-waste management.

Despite full awareness of the threats posed by clinical waste, including waste being dangerous to people, there are still problems with proper clinical-waste management.
It needs to be stressed that despite the fact that there have not been any legal grounds in force laying down the methods of clinical-waste management, including hazardous waste, for over a year now, such a legal loophole cannot justify the conduct of the inspected hospitals ${ }^{1}$. As the sanitary inspection declares, most of the healthcare institutions, despite the legal loophole, apply the provisions of the old Regulation of the Minister of Health of 30 July 2010 on the detailed methods of clinicalwaste management, which ceased to be applicable in January 2016. The fact that there are no applicable legal regulations does not mean that the sanitary inspection will not supervise clinical-waste management in hospitals, which has been confirmed by the results of the presented inspections. The following legal regulations apply here: the Act on Waste [Ustawa...2012], the Act on Preventing and Fighting Infections and Infectious Diseases in People [Ustawa...2008] and the Building Law Act [Ustawa... 1994].

1 Legal status as of 4 October 2017

\section{REFERENCES AND LEGAL ACTS}

DUANE TH.M., BROWN H., BORCHERS C.T., L.G. i in. 2009, A Central Venous Line protocol decreases bloodstream infections and length of stay in a trauma intensive care unit population, 'Am. Surg., 75 (12), s.1166-1171.

FURTAK-NICZYPORUK M. 2012, Organizacja unieszkodliwiania niebezpiecznych odpadów medycznych (w:) Ocena modelu prawnego organizacji ochrony środowiska w Polsce i na Słowacji, pod red. E. Ury, J. Stelmasiaka, S. Pieprznego, Wyd. Uniwersytet Rzeszowski, Rzeszów, s.436-456.

FURTAK-NICZYPORUK M. 2013, Proces gospodarowania niebezpiecznymi odpadami medycznymi w świetle obowiązującego prawa (w:) Prawo w ochronie zdrowia, pod red. M. Szewczaka, B. Dropa, R. Śmiecha, Wyd. KUL, Lublin, s.87.

FURTAK-NICZYPORUK M. 2015, Warunki transportu niebezpiecznych odpadów medycznych, Białostockie Studia Prawnicze, Zeszyt 18, Wyd. Uniwersytetu w Białymstoku, Białystok, s.99-111.

GÓRSKI M. 2005, Gospodarowanie odpadami w świetle wymagań prawa wspólnotowego i polskiego prawa wewnętrznego, Poznań, s.41.

GÓRSKI M. 2009, Gospodarowanie odpadami (w:) Prawo ochrony środowiska, pod. red. M. Górskiego, Wolters Kluwer, Warszawa, s.311.

KORZENIOWSKI P. 2014, Model prawny systemu gospodarki odpadami. Studium administracyjno-prawne, Wyd. Uniwersytetu Łódzkiego, Łódź, s.213.

MICHALAK J. 2012, Zakażenia szpitalne jako przedmiot działań organizacji międzynarodowych (w:) Zakażenia szpitalne. Wybrane zagadnienia, pod. red. A. Denys, Wolters Kluwer, Warszawa, s.291-319.
Rozporządzenie Ministra Środowiska z dnia 13 stycznia 2014 r. w sprawie dokumentu potwierdzającego unieszkodliwienie zakaźnych odpadów medycznych lub zakaźnych odpadów weterynaryjnych (Dz. U. 2014 r., poz. 107).

Rozporządzenie Ministra Środowiska z dnia 9 grudnia 2014 r. w sprawie katalogu odpadów (Dz. U. z 2014 r. poz. 1923).

Rozporządzenie Ministra Zdrowia z dnia 24 lipca 2015 r. w sprawie rodzajów odpadów medycznych i odpadów weterynaryjnych, których odzysk jest dopuszczalny (Dz. U. z 2015 r. poz. 1116).

Rozporządzenie Ministra Zdrowia z dnia 21 października 2016 r. w sprawie wymagań i sposobów unieszkodliwienia odpadów medycznych i weterynaryjnych (Dz. U. z 2016 r. poz. 1819).

Ustawa z dnia 7 lipca 1994 r. Prawo budowlane (tekst jedn.: Dz. U. z 2016, poz. 290), art.5 ust. 2.

Ustawa z dnia 5 grudnia 2008 r. o zapobieganiu oraz zwalczaniu zakażeń i chorób zakaźnych u ludzi (tekst jedn.: Dz. U. z 2016 r. poz.1866 z późn. zm.) art. 22, ust. 1 ; rozdz. 3 i 5.

Ustawa z dnia 19 sierpnia 2011 r. o przewozie towarów niebezpiecznych (tekst jedn.: Dz. U. z 2016 r., poz. 1834).

Ustawa z dnia 14 grudnia 2012 r. o odpadach (tekst jedn.: Dz. U. z 2016 r., poz. 1987 z późn. zm.) art. 3 ust. 1 pkt 2); art. 3 ust. 1 pkt 34); art. 3 ust. 1 pkt 6. 